\title{
The evaluation of PDI concentrations in some ruminant feedstuffs: a comparison of in situ and in vitro protein degradability
}

\author{
P. Susmel, B. Stefanon, C.R. Mills and M. Colitti
}

Istituto di Produzione Animale, via S. Mauro 2, 33010 Pagnacco, Italy

(Received 11 April 1989; accepted 19 October 1989)

\begin{abstract}
Summary - The effective rumen degradability $(\mathrm{Dg})$ of dry matter (DM), nitrogen $(\mathrm{N})$ and nonprotein organic matter (NPOM) of 16 commonly used ruminant feedstuffs was measured in situ. The PDIA, PDIE and PDIN contents of the feedstuffs were calculated either using the DgN and DgNPOM in situ values or using the $\mathrm{DgN}$ and fermentable organic matter (MOF) data derived from INRA tables. The regressions between values from the 2 systems had high $r^{2}$ values, but only agreed closely for PDIN values. The difference between PDIA values calculated using the 2 systems was small, but PDIE values differed considerably. The in vitro enzymatic degradability of the same 16 feeds was also measured, using protease extracted from Streptomyces griseus. The $1-h$ enzymatic degradability of the feeds was higher than the value in situ, except for the maizemeal and forages. However, protease degradability after $24 \mathrm{~h}$ was lower than the effective degradability in situ. Only the animal proteins deviated from this rule. Significant correlations were found between the coefficient $a$ in situ and as and $b s$ in vitro, and between $b s$ in vitro and $b$ in situ. The effective degradability in situ was highly correlated with the enzymatic degradability.
\end{abstract}

in situ degradability - PDI — in vitro degradability

Résumé - Teneur en PDI des aliments pour les ruminants. Comparaison entre la dégradabilité de l'azote in sacco et in vitro. La dégradabilité théorique dans le rumen (Dg) de la matière sèche (MS), l'azote (N) et la fraction non azotée de la matière organique (NPOM) de 16 aliments classiquement utilisés dans les rations des ruminants a été mesurée in sacco. Les teneurs en PDIA, PDIE et PDIN des aliments ont été calculées en utilisant soit les valeurs de DgN et de DgNPOM obtenues in sacco, à travers le système proposé par Susmel et Stefanon (1987), soit les valeurs de $\mathrm{DgN}$ et la matière organique fermentescible (MOF) proposées dans le système INRA (1988). Une bonne correspondance a été trouvée entre les valeurs de PDIN calculées en utilisant soit la dgN calculée dans cette étude et la dgNPOM, soit la dgN donnée par l'INRA (1988) et la MOF, tandis qu'une différence non négligeable a été trouvée pour les teneurs en PDIE. La dégradabilité enzymatique in vitro des mêmes aliments a été mesurée avec une méthode enzymatique utilisant une protéase extraite de Streptomyces Griseus, en incubant un échantillon de chaque aliment pendant 1 (as) et 24 (bs) h. La dégradabilité enzymatique de l' $\mathrm{N}$ des aliments as a été plus élevée que les valeurs mesurées in sacco (a), excepté pour le maîs et les fourrages, et la dégradabilité enzymatique $a s+b s$ a été tout le temps inférieure à la valeur $a+b$ mesurée in sacco, sauf pour les farines de viande et de poisson. Une corrélation significative a été observée entre la dégradabilité a mesurée in sacco et la dégradabilité enzymatique as et bs. Une bonne corrélation a été aussi observée entre les valeurs $b$ in sacco et $b s$ in vitro.

dégradabilité in sacco - PDI- degradabilité in vitro 


\section{INTRODUCTION}

The in situ technique using the methodology of Ørskov and McDonald (1979) is the method most frequently used for the measurement of rumen $\mathrm{N}$ degradation. The values obtained were incorporated in the new protein systems (ARC, 1984; INRA, 1988; Madsen, 1985; NRC, 1985; Susmel \& Stefanon, 1987). The use of this technique permits the simultaneous estimation of nitrogen (N), dry matter (DM) and nonprotein organic matter (NPOM) degradability, and can therefore be used to estimate the quantity of energy available for bacterial growth (Susmel \& Stefanon, 1987). The effective degradability of $\mathrm{N}$ and NPOM can subsequently be used to estimate the protein value of feedstuffs (Susmel \& Stefanon, 1987).

A large number of factors influence the in situ degradability of feedstuffs, the most important of which appears to be diet formulation (Weakley et al., 1983; Susmel et al., 1989). Preliminary results obtained in a United Kingdom ring test (Oldham, 1987) showed that there is poor reproducibility between laboratories measuring in situ $\mathrm{N}$ degradability. In situ degradability measurements are also expensive and time consuming.

The evaluation of degradability in vitro allows, at least from a theoretical point of view, better control over the factors responsible for the variation, and hence improved repeatability and reproducibility in the degradability values obtained. In vitro techniques also avoid the use of animals and are thus generally less expensive both in terms of time and money.

Techniques based upon $\mathrm{N}$ solubility in buffers generally do not show high correlations with degradability values obtained in vivo (Crawford et al., 1978; Crooker et al., 1978; Krishnamoorthy et al., 1982; Mad- sen \& Hvelplund, 1985; Stern \& Satter, 1984). However, high correlation coefficients (with $r^{2}$ values ranging from 0.61 to 0.90 ) have been obtained comparing in vitro degradability using proteolityc enzymes and in vivo values (Krishnamoorthy et al., 1983; Poos-Floyd et al., 1985; Sauvant et al., 1987; Broderick et al., 1988).

The enzymatic technique proposed by Aufrere and Cartailler (1988) was applied to some ruminant feedstuffs to test its capability to predict in situ protein degradability. The PDI concentrations obtained from in situ degradability using the Susmel and Stefanon (1987) system were compared with those obtained using reference French methods and values (Vérité et al., 1987).

\section{MATERIAL AND METHODS}

\section{In situ trial}

The rumen degradability of dry matter (DM), nitrogen $(\mathrm{N})$ and non-protein organic matter (NPOM) was measured for the following feedstuffs: wheat, maize, barley, whole soyabean meal, dried molassed sugar beet pulp, dried brewers' grains $\left(60^{\circ} \mathrm{C}\right)$, maize gluten meal, sunflower meal, cottonseed cake, linseed cake, extracted soyabean meal, meat meal, fishmeal, maize silage (dough stage), lucerne hay (second cut, full bloom stage) and lucerne silage (autumn third cut, midbloom stage, direct cut with microbial additive; Derasyl, Ceva, France). The proximate analysis of the feeds is shown in Table I.

The lucerne hay, lucerne silage and maize silage were incubated "fresh" after having been chopped to give an average particle length of less than $20 \mathrm{~mm}$. The other protein concentrates and by-products were hammermilled through a 2-mm screen.

The in situ rumen degradability was measured using the nylon bag technique (Ørskov \& 
Table I. Proximate analyses of feeds ( $\mathrm{g} / \mathrm{kg} \mathrm{DM})$.

\begin{tabular}{|c|c|c|c|c|c|c|}
\hline & $D M$ & $\begin{array}{c}\text { Crude } \\
\text { Protein }\end{array}$ & Ash & $\begin{array}{l}\text { Ether } \\
\text { Extract }\end{array}$ & $\begin{array}{l}\text { Crude } \\
\text { Fibre }\end{array}$ & $\begin{array}{c}N \text {-free } \\
\text { Extract }\end{array}$ \\
\hline Wheat & 864 & 143 & 29 & 13 & 33 & 782 \\
\hline Maize meal & 864 & 85 & 16 & 31 & 31 & 837 \\
\hline Barley & 879 & 106 & 35 & 15 & 72 & 772 \\
\hline Whole soyabean meal & 955 & 418 & 57 & 139 & 150 & 236 \\
\hline Dried mol. sugarbeet pulp & 898 & 103 & 60 & 5 & 208 & 624 \\
\hline Dried brewers' grains & 938 & 268 & 42 & 83 & 176 & 431 \\
\hline Maize gluten meal & 896 & 602 & 54 & 19 & 19 & 306 \\
\hline Sunflower meal & 904 & 353 & 76 & 18 & 235 & 318 \\
\hline Cottonseed cake & 943 & 300 & 54 & 67 & 234 & 345 \\
\hline Linseed cake & 917 & 345 & 71 & 50 & 127 & 407 \\
\hline Soyabean meal sol. ext. & 886 & 524 & 70 & 8 & 37 & 361 \\
\hline Meat meal & 970 & 589 & 293 & 101 & 13 & 4 \\
\hline Fishmeal & 911 & 672 & 185 & 76 & 5 & 62 \\
\hline Lucerne hay & 898 & 187 & 90 & 20 & 274 & 429 \\
\hline Ensiled lucerne & 220 & 169 & 181 & 42 & 261 & 347 \\
\hline Maize silage & 362 & 72 & 34 & 29 & 198 & 667 \\
\hline
\end{tabular}

McDonald, 1979). Details of the method have been published previously (Susmel \& Stefanon, 1987). A minimum of 4 rumen fistulated cows are required and are fed a basal diet composed of $50 \%$ (dry matter basis) concentrate, $25 \%$ meadow hay and $25 \%$ maize silage. The concentrate is formulated to contain at least 3 protein sources, at least 1 of which is an animal protein; the protein content is sufficient to maintain a dietary crude protein concentration of 130 $\mathrm{g} / \mathrm{kg}$ DM and a positively balanced PDIE-PDIN ratio. The basal diet is offered in 2 equal meals (at 07.30 and 16.30) and rationed so that the dry matter intake is approximately $15 \mathrm{~g} \mathrm{DM} / \mathrm{kg}$ liveweight. Concentrates and hay are dried at $65^{\circ} \mathrm{C}$ and sieved through 40- and 2000- $\mu \mathrm{m}$ sieves before incubation. Polyester bags with a pore size of approximately $40 \mu \mathrm{m}$ are filled with a quantity of feed sample to give a dry matter weight: free bag surface area of $12.5 \mathrm{mg} \mathrm{DM} /$ $\mathrm{cm}^{2}$. Silages are incubated as fed, after having been cut into small pieces (between 0.5 and
$2.0 \mathrm{~cm}$ ); a quantity equivalent to $12.5 \mathrm{mg} \mathrm{DM} /$ $\mathrm{cm}^{2}$ bag area is incubated in each bag. Duplicate bags are introduced into the rumen immediately after the morning meal, attached to a nylon rope of a length corresponding to the distance between the cannula lid and the bottom of the ventral sac of the cow's rumen; the rope is kept under tension with a 1-kg iron weight. "Zero time" bags are allowed to soak in rumen liquid in situ for about $3 \mathrm{~min}$. After incubation, bags are rinsed briefly in a bucket of cold water and then put through the cold rinse cycle of an automatic washing machine prior to drying at $65^{\circ} \mathrm{C}$.

In the present experiment, the concentrates and by-products were incubated for $0,2,6,12$, 24 and $48 h$; the forages were also incubated for $72 \mathrm{~h}$.

Due to the large number of feeds to be incubated, the trial was conducted in $\mathbf{3}$ consecutive periods. 8 rumen fistulated Simmental cows (average liveweight $630 \pm 12 \mathrm{~kg}$ ), were used. For each experimental period, the cows were 
subdivided into 2 groups of 4 animals each; in the first period, the maize silage, maize and dried molassed sugarbeet pulp were incubated in group 1 , whilst the maize gluten meal, lucerne hay and whole soyabean meal were tested in group 2. In the second period, the cottonseed cake, meat meal and wheat were incubated in group 1 cows and linseed meal, barley and sunflower meal in group 2 animals. In the third period, the extracted soyabean meal, dried brewers' grains, ensiled lucerne and fishmeal were incubated in group 1 animals.

The basal diet (CP content $135 \mathrm{~g} / \mathrm{kg}$ DM, PDIE-PDIN balance $+60 \mathrm{~g}$ ) was composed of $25 \%$ (DM basis) maize silage (DM, $377 \mathrm{~g} / \mathrm{kg}$; $\mathrm{CP}, 76 \mathrm{~g} / \mathrm{kg}$; CF, $206 \mathrm{~g} / \mathrm{kg}$ ), 25\% permanent pasture hay (DM, $905 \mathrm{~g} / \mathrm{kg}$; $\mathrm{CP}, 91 \mathrm{~g} / \mathrm{kg}$; CF, $376 \mathrm{~g} / \mathrm{kg}$ ) and $50 \%$ concentrate (DM, $874 \mathrm{~g} / \mathrm{kg}$; $\mathrm{CP}, 191 \mathrm{~g} / \mathrm{kg}$; CF, $57 \mathrm{~g} / \mathrm{kg}$ ) containing $69 \%$ maize, $12 \%$ soyabean meal, $9 \%$ sunflower meal, $7 \%$ meat meal and $3 \%$ mineral-vitamin supplement. Before each incubation period, the animals ate the basal diet for at least 21 days. In total, the trial lasted 3 months.

\section{In vitro trial}

The in vitro enzymatic degradability of the same 16 feeds used in the in situ trial was measured using the technique of Aufrere and Cartailler (1988). This method requires that the feeds be incubated for 1 and $24 \mathrm{~h}$ in a phosphoborate buffer containing protease extracted from Streptomyces griseus.

The enzyme solution was obtained by mixing $2 \mathrm{~g}$ of $S$. griseus protease (type XIV, Sigma no. P-5147; 4.7 titratable units $/ \mathrm{mg}$ ) with $1000 \mathrm{ml}$ of phosphoborate buffer ( $\mathrm{pH} 8.0, \mathrm{PBB})$, prepared by disolving $12.20 \mathrm{~g} \mathrm{Na}_{2} \mathrm{HPO}_{4}$ and $8.91 \mathrm{~g}$ $\mathrm{Na}_{2} \mathrm{~B}_{4} \mathrm{O}_{7} 1 \mathrm{H}_{2} \mathrm{O}$ in distilled water, adjusting the $\mathrm{pH}$ to 8 with $1 \mathrm{~N} \mathrm{NaOH}$ and making up to 1000 $\mathrm{ml}$. Each sample $(0.5 \mathrm{~g})$ was incubated in an $80-\mathrm{ml}$ pyrex tube, with $0.5 \mathrm{ml}$ enzyme solution and $0.5 \mathrm{ml}$ tetracycline solution (Sigma no. T$3258,100 \mathrm{mg} /$ ( PBB). At the beginning of the incubation period, $0.5 \mathrm{mg}$ nistatin (Sigma no $\mathrm{N}$ 3503) and $50 \mathrm{ml} \mathrm{PBB}$ was added to each tube.

Before incubation, the maize and lucerne silages were dried at $60^{\circ} \mathrm{C}$ for $48 \mathrm{~h}$. The hay, the concentrate feeds and the by-products were milled to pass a $1-\mathrm{mm}$ screen. Each sample was incubated in duplicate in 2 batches in a waterbath at $40^{\circ} \mathrm{C}$ for 1 and $24 \mathrm{~h}$. In each batch, the 1- and 24-h degradability of extracted soyabean meal was used as an internal standard; duplicate blank tubes were present in each batch. The 24-h tubes were swirled manually after $1,2,3,4,5,6,7$ and $12 \mathrm{~h}$; all tubes were cooled and centrifuged for $5 \mathrm{~min}$ at $3000 \mathrm{rpm}$ after incubation.

A $10-\mathrm{ml}$ aliquot of supernatant was taken from each tube for nitrogen analysis. The quantity of $\mathrm{N}$ rendered soluble was calculated as the fraction of that present before incubation, after adjustments for the relative blanks and the average change in $1-$ and $24-h$ solubility of the soya standards between the 2 batches. The quantity of $\mathrm{N}$ rendered soluble (degraded) after 1 and $24 \mathrm{~h}$ will be refered to as as and as $+b s$ respectively (Ørskov \& MacDonald, 1979) (model (i) below).

The repeatability of the in vitro experiment was tested using the ISO (1981) method, incubations were repeated when the coefficient of variation (CV) exceeded $2 \%$.

\section{Chemical analyses}

The chemical composition and dry matter content of the feeds were determined using standard AOAC (1975) methodology. The N content of each feedstuff before incubation and each supernatant was determined using the micro Kjeldhal technique with samples weighing approximately $200 \mathrm{mg}$.

\section{Statistical analysis}

The in situ degradability kinetics for nitrogen, dry matter and non-protein dry matter (calculat-ed as the difference between dry matter and crude protein weights in the bag residues) were studied using the 2-component exponential model proposed by Ørskov \& McDonald (1979) using the Marquardt algorithm for non-linear regression analysis (SPSSx, 1985):

$$
D g(t)=a+b\left(1-\theta^{(-c t)}\right)
$$


where $\mathrm{Dg}(t)=$ degradability at time $t ; a=$ intercept of the degradability curve on the $y$-axis (solubility); $b=$ curve asymptote at infinite time; $c=$ instantaneous rate of change of degradability. The following boundaries were used: $100>a$ $>0 ; 100>b>0 ; a+b<100 ; 1>c>0$.

The effective degradability ( $\mathrm{Dg}$, corresponding to the degradabilite theorique in the French protein system proposed by Vérité et al., 1987) was calculated, weighted to account for rumen outflow rate, using the equation of Ørskov and McDonald (1979) :

$$
\mathrm{Dg}=a+(b c) /(c+k)
$$

where $a, b$ and $c$ are as in eq. (1) and $k$ is the rumen outflow rate.

A rumen outflow rate of $0.07 / \mathrm{h}$ was used for the concentrate feeds, this value having been observed previously with basal diets of similar composition and intake level (Stefanon \& Ovan, 1988 ), whilst a rate of $0.04 / \mathrm{h}$ was used for the forages in an attempt to account for differences in composition and particle size (Colucci et al., 1982).

\section{Calculation of PDIA and PDIE}

Susmel and Stefanon (1987) have assumed that the effective degradability of non-protein organic matter (DgNPOM, \%) is equal to the effective degradability of non-protein dry matter multiplied by the feed concentrations of crude fibre and nitrogen-free extracts. This has recently been supported by the regression of the effective degradability of organic matter (DgOM) and dry matter (DgDM) to give the following equation (Susmel \& Stefanon, unpublished data):

$$
\begin{gathered}
\mathrm{DgSO}=1.049 \times \mathrm{DgDM}-0.044 \\
r^{2}=0.923 ; \mathrm{RSE}=0.022 ; \mathrm{DF}=21
\end{gathered}
$$

Total fermented carbohydrates $(C, g)$ can then be considered as:

$C=D g N P O M \times(C F+N F E) / 100$

with CF and NFE in $\mathrm{g} / \mathrm{kg}$.

The PDIA, PDIE and PDIN contents of the feedstuffs were calculated as follows:

(a) using the DgN and DgNPOM in situ values with the system proposed by Susmel and Stefanon (1987); (b) Using the DgN, the undegraded amino acid true digestibility in the small intestine $(d r)$ and fermentable organic matter data derived from INRA tables and the system proposed by Vérité et al. (1987).

The protein system proposed by Susmel \& Stefanon (1987) has not previously been published in English, so a brief summary of the equations used is presented below.

(i) $\mathrm{PDIA}=g \mathrm{~N} \times 6.25 \times(1-\mathrm{DgN} \% / 100) \times \mathrm{dr}$ $\times 0.85$

where $\mathrm{PDIA}=$ feed protein digestible in the small intestine; $d r=$ true protein digestibility.

$d r=[(1-D g N \% / 100) \times N \times 6.25-(0.1 \times N \times 6.25)]$ $/[(1-D g N \% / 100) \times N \times 6.25)]$

where 0.85 = fraction of amino acids in the undegraded protein; $\mathrm{DgN} \%=\%$ effective protein degradability.

(ii) $\mathrm{PD} \mid \mathrm{ME}=((0.030 \times \mathrm{C})+(0.015 \times \mathrm{P}) \times 14.0$ $\times 0.53 \times 0.80 \times 0.85$

where PDIME = potential bacterial protein synthesis as a function of energy when nitrogen supply is not limiting;

$\mathrm{P}=\mathrm{g}$ degraded protein; $\mathrm{C}=\mathrm{g}$ fermented carbohydrate (NPOM); $0.030=$ ATP yield (moles) per $\mathrm{g}$ fermented carbohydrate in the rumen; $0.015=$ ATP yield (mol) per $g$ fermented protein in the rumen; $14.0=$ microbial $D M$ synthesised $/ \mathrm{mol}$ ATP; 0.53 = fraction of protein in microbial DM; 0.80 = fraction of aminoacid in microbial protein; $0.85=$ microbial protein digestibility. $\times 0.85$

(iii) PDIMN $=N \times 6.25 \times(\mathrm{DgN} \% / 100) \times 0.80$

where PDIMN = potential bacterial protein synthesis as a function of nitrogen when energy is not limiting; $0.80=$ fraction of amino acid in the microbial protein; $0.85=$ microbial protein digestibility.

$$
\begin{aligned}
& \text { (iv) } \mathrm{PDI}=\mathrm{PDIE} \quad \text { (if } \mathrm{PDIE}<\mathrm{PDIN} \text { ) } \\
& \text { PDI }=\text { PDIN (if PDIE }>\text { PDIN) }
\end{aligned}
$$

\section{RESULTS}

RSE values for the $\mathrm{N}$ degradability kinetics (Table II) were generally high (i.e., more than 1); goodness of fit with the model was 
variable between feeds, with $r^{2}$ values between 0.74 and 0.97 . Values for maize meal, maize gluten meal, cottonseed cake and the 2 silages were found to fit the model least well (Table II).

The effective degradability of $\mathrm{N}(\mathrm{DgN}$, Table III) was always higher than $50 \%$ in the cereals and whole soya, the highest value being $74 \%$ for wheat. $\mathrm{DgN}$ for the by-products was much lower, with the maize gluten meal value very low at $30 \%$. The $\mathrm{DgN}$ values for the vegetable and animal proteins were very variable.

The high $\mathrm{N}$ degradability in sunflower meal and cottonseed cake was particularly noticeable, this being associated with high initial solubility (a). The meatmeal was more degradable than the fishmeal. Of the 3 forages, the lucerne silage had a higher proportion of undegradable protein, higher even than the lucerne hay.

The effective degradability of DM (DgDM, Table III) was low (approximately $40 \%$ ) in brewers' grains, maize gluten meal, cottonseed cake, linseed meal, fishmeal and meatmeal. It was higher (approximately $60 \%$ ) in the cereals and soyabean meal.

The effective degradability of NPOM (Table III) was much more variable between feedstuffs than the $\mathrm{DgN}$ and $\mathrm{DgDM}$ values. Wheat again had the highest value $(81 \%)$, followed by soyabean meal $(68 \%)$; low values of DgNPOM (between 7 and $39 \%$ ) were observed for meatmeal, fishmeal, cottonseed and linseed cake, dried brewer's grains and ensiled lucerne.

The effective degradability of $\mathbf{N}$ was only partly correlated with that of DM ( $r=$ $0.65)$, and was independent of NPOM degradability $(r=0.40)$, whilst, as expected, a high correlation was observed between DgDM and DgNPOM ( $r=0.92)$. In particular, of the cereals, wheat and barley had $N$ and NPOM degradability similar to that of $\mathrm{DM}$, but this was not the case with the maize meal, where the $\mathrm{DgN}$ value was lower than DgDM. The $\mathrm{DgN}$ value of the oil

Table II. Coefficients of degradability kinetics, RSE and $r^{2}$ values of nitrogen.

\begin{tabular}{lrrrrr}
\hline & $a$ & $b$ & $c$ & RSE & $r^{2}$ \\
\hline Wheat & 12.1 & 86,7 & 0,1710 & 1.5 & 0.91 \\
Maize meal & 30.1 & 69.9 & 0.0317 & 1.5 & 0.79 \\
Barley & 16.7 & 75.7 & 0.1080 & 1.1 & 0.93 \\
Whole soyabean meal & 19.4 & 80.6 & 0.0492 & 1.0 & 0.93 \\
Dried mol. sugarbeet pulp & 8.9 & 91.1 & 0.0392 & 1.6 & 0.88 \\
Dried brewers' grains & 13.5 & 62.7 & 0.0640 & 0.5 & 0.97 \\
Maize gluten meal & 7.4 & 92.6 & 0.0220 & 1.6 & 0.82 \\
Sunflower meal & 30.3 & 65.4 & 0.1581 & 0.6 & 0.97 \\
Cottonseed cake & 32.2 & 55.8 & 0.0876 & 1.4 & 0.81 \\
Linseed cake & 5.2 & 94.8 & 0.0377 & 1.3 & 0.91 \\
Soyabean meal sol. ext. & 18.4 & 81.6 & 0.0490 & 1.1 & 0.90 \\
Meat meal & 19.5 & 48.8 & 0.1339 & 1.0 & 0.87 \\
Fishmeal & 23.2 & 26.2 & 0.1070 & 0.4 & 0.90 \\
Lucerne hay & 37.2 & 55.7 & 0.0568 & 0.8 & 0.94 \\
Ensiled lucerne & 40.5 & 24.7 & 0.0477 & 0.6 & 0.74 \\
Maize silage & 63.0 & 37.0 & 0.0083 & 0.5 & 0.75 \\
\hline
\end{tabular}


Table III. Effective degradability of $\mathrm{N}(\mathrm{DgN})$, dry matter (DgDM) and non-protein organic-matter (DgNPOM) and PDI concentrations of feedstuffs.

\begin{tabular}{lrrrrrr}
\hline & $D g N$ & $D g D M$ & $D g N P O M$ & $P D I A$ & $P D I E$ & $P D I N$ \\
\hline Wheat & 73.6 & 79.6 & 80.7 & 20 & 127 & 91 \\
Maize meal & 51.9 & 60.5 & 61.3 & 28 & 111 & 57 \\
Barley & 62.6 & 60.0 & 59.7 & 25 & 106 & 69 \\
Whole soyabean meal & 52.7 & 55.6 & 57.7 & 133 & 170 & 282 \\
Dried mol. sugarbeet pulp & 41.6 & 47.5 & 48.2 & 42 & 110 & 72 \\
Dried brewers' grains & 43.4 & 33.2 & 29.7 & 106 & 142 & 185 \\
Maize gluten meal & 29.5 & 34.4 & 43.4 & 309 & 344 & 430 \\
& & & & & & \\
Sunflower meal & 75.6 & 54.0 & 42.2 & 43 & 98 & 225 \\
Cottonseed cake & 63.2 & 38.0 & 27.1 & 68 & 106 & 197 \\
Linseed cake & 38.4 & 34.3 & 32.7 & 151 & 188 & 241 \\
Soyabean meal sol. ext. & 52.0 & 60.0 & 68.4 & 169 & 231 & 355 \\
& & & & & & \\
Meat meal & 51.6 & 31.9 & 6.9 & 192 & 215 & 399 \\
Fishmeal & 39.1 & 32.6 & 20.7 & 291 & 312 & 469 \\
& & & & & & \\
Lucerne hay & 69.9 & 56.6 & 53.5 & 44 & 100 & 123 \\
Ensiled lucerne & 54.0 & 41.0 & 38.8 & 57 & 94 & 115 \\
Maize silage & 69.3 & 55.9 & 54.9 & 14 & 88 & 47 \\
\hline
\end{tabular}

$\mathrm{DgN}, \mathrm{Dg} D \mathrm{DM}, \mathrm{DgNPOM}=a+b\left(1-e^{(-t)}\right)$.

$\mathrm{DgN}, \mathrm{Dg} \mathrm{DM}, \mathrm{DgNPOM}=a+(b c) /(c+k)$, with $k=0.07 / \mathrm{h}$ for concentrate and by-products and $0.04 / \mathrm{h}$ for forages.

seed meals and cakes (with the exception of the extracted soyabean meal), of the animal proteins and the forages were noticeably higher than the DgDM values.

The PDIA, PDIE and PDIN concentrations of the 16 feedstuffs, estimated using the system proposed by Susmel \& Stefanon (1987), are reported in Table III. Figures 1,2 and 3 show the regression equations and the plots of the feed concentrations of PDIA, PDIE and PDIN calculated using the INRA (Vérité et al., 1987) method with values obtained using the Susmel \& Stefanon (1987) method.

The regressions, calculated by taking the Italian values as independent variables, show a high degree of correlation.
However, the 2 protein systems only agree closely for PDIN values, with the gradient equal to $1.1(P<0.001)$. The differences between the PDIA and PDIE values calculated using the 2 systems are consistent, with gradients equal to 1.3 and 1.4 respectively $(P<0.001)$. The constant terms of the regressions for PDIA, PDIE, and PDIN were not found to be significantly different from zero.

Table IV shows the results of the in vitro protease degradability experiment. The 16 feeds showed variable degradability values: from $8.1 \%$ for maize gluten meal to $62.1 \%$ for sunflower meal, and from $41.6 \%$ for whole soyabean meal to $84.7 \%$ for sunflower meal after 1 and $24 \mathrm{~h}$ respectively. 


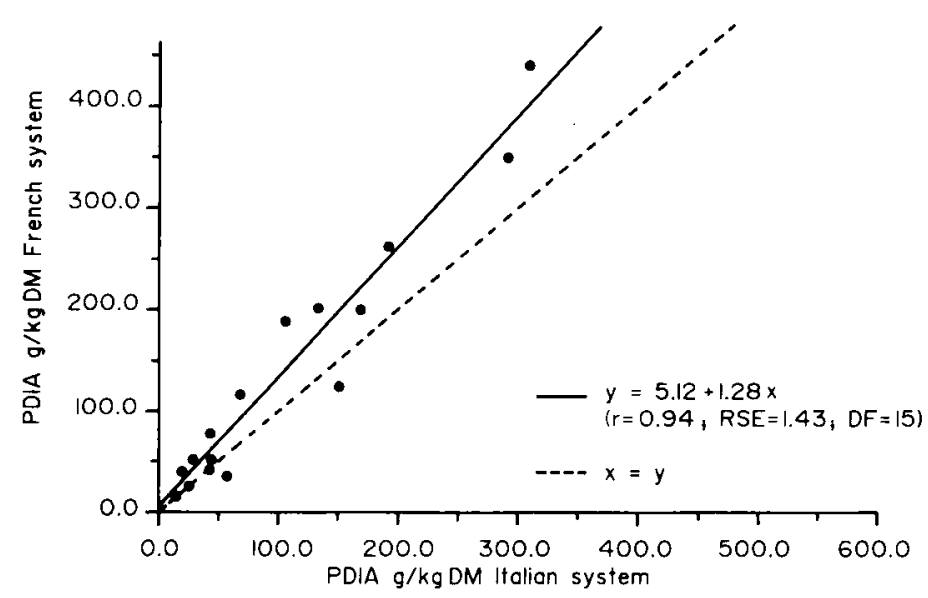

Fig. 1. Regression of PDIA concentrations calculated using the INRA system with data obtained using the Italian system.

Table IV also shows the calculated times (CTs, h) at which the in situ degradability equals the $1-$ or $24-h$ in vitro degradability; these times vary greatly between feeds, as is evident from the standard deviations. The enzymatic degradability as (after $1 \mathrm{~h}$; Table III) of the feeds was higher than the a value in situ
(Table II), except for the maize meal and the forages. This is shown by positive CTs in Table IV, with negative values for the maize meal and forages. After $24 \mathrm{~h}$, degradability in vitro (as + bs) was considerably lower for the cereals, whole soyabean meal, sunflower meal, cottonseed cake, lucerne hay and maize silage, with CTs con-

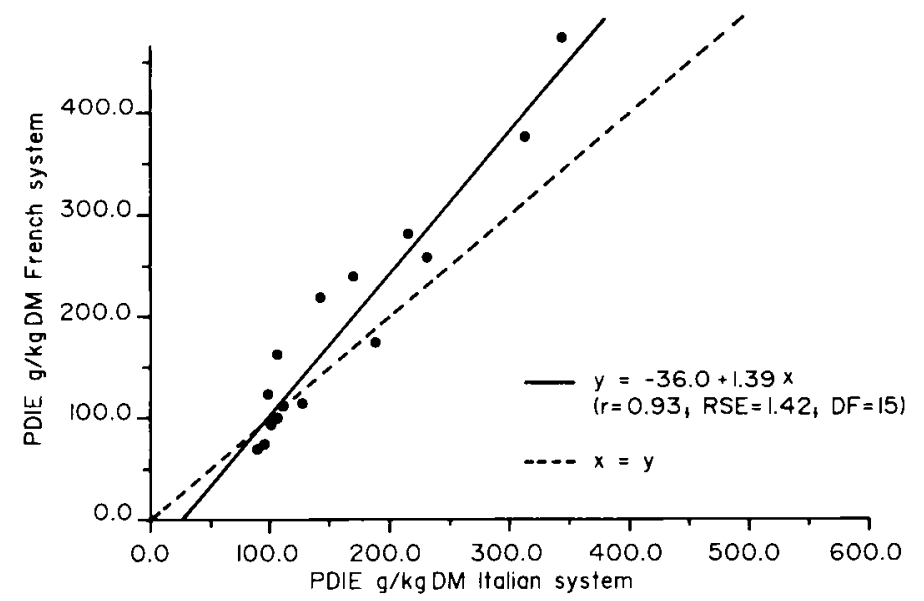

Fig. 2. Regression of PDIE concentrations calculated using the INRA system with data obtained using the Italian system. 


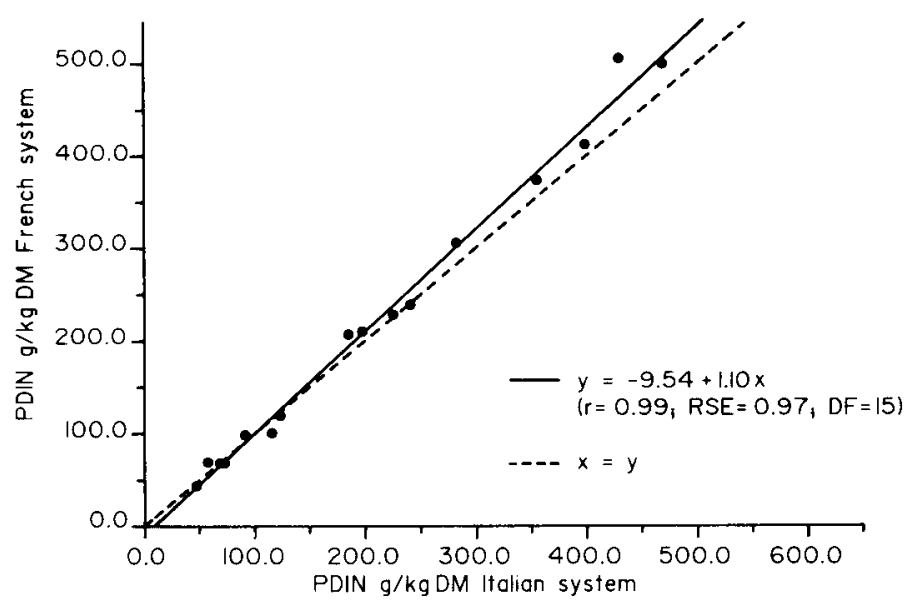

Fig. 3. Regression of PDIN concentrations calculated using the INRA system with data obtained using the Italian system.

siderably less than the 24-values. Only fishmeal had a higher $24-\mathrm{h}$ in vitro degradability than the $a+b$ in situ value.

Table $V$ shows the correlation coefficients $(r)$ between degradability in vitro and degradability in situ of the 16 feeds. Significant correlations were found between the coefficient $a$ in situ and as and $b s$ in vitro, and between bs in vitro and $b$ in situ. Significant correlations were also found between in situ effective degradability $(\mathrm{DgN})$ and the in vitro degradability values as, as + bs and bs.

Having considered the results in Table $V$, the possibility of a relationship between as and $a s+b s$ values with the effective nitrogen degradability in situ was investigated using multiple regression analysis.

The regression equation for all the feeds (group 1) was

$$
\begin{gathered}
\mathrm{DgN}=0.78 \times \text { as }-0.10 \times(a s+b s)+33.5 \\
\left(r^{2}=0.61 ; \mathrm{RSE}=2.32\right)
\end{gathered}
$$

The coefficient for as and the constant term were significant $(P<0.01$ and $P<$ 0.05 respectively).
The plot of standardised residuals with standardised degradability values is shown in Fig. 4. Multiple regression analysis of the feeds within the range of \pm 1 standardised residual units (maize, whole soyabean meal, dried molassed sugarbeet pulp, maize gluten meal, brewers' grains, sunflower meal, cottonseed cake, linseed cake, meat meal, ensiled lucerne and maize silage) gave a higher $r^{2}(0.88)$ and RSE (1.31) values with the following equation:

$\mathrm{DgN}=0.92 \times$ as $-0.30 \times(a s+b s)+40.9$ with the coefficient for as and the constant significantly different from zero $(P<0.01)$.

\section{DISCUSSION}

The basal diet was formulated to be as similar as possible to production rations for lactating dairy cows, within the constraints of the experimental design (Susmel \& Stef- 
Table IV. Protease degradability of nitrogen after 1 and $24 \mathrm{~h}$ of incubation and the time this value would occur in situ. (CTs) calculated using the kinetics reported in Table II.

\begin{tabular}{|c|c|c|c|c|}
\hline \multirow[t]{2}{*}{ Feed } & \multicolumn{2}{|c|}{ Degradability } & \multicolumn{2}{|c|}{$\mathrm{CT}^{\mathrm{a}}$} \\
\hline & $\begin{array}{r}1 \mathrm{~h} \\
\text { as }\end{array}$ & $\begin{array}{r}24 \mathrm{~h} \\
a s+b s\end{array}$ & $1 \mathrm{~h}$ & $24 \mathrm{~h}$ \\
\hline $\begin{array}{l}\text { Wheat } \\
\text { Maize meal } \\
\text { Barley } \\
\text { Whole soyabean meal }\end{array}$ & $\begin{array}{l}49.8 \\
23.7 \\
32.7 \\
19.9\end{array}$ & $\begin{array}{l}71.3 \\
45.6 \\
65.9 \\
41.6\end{array}$ & $\begin{array}{r}3.3 \\
-2.8 \\
2.2 \\
0.1\end{array}$ & $\begin{array}{l}6.7 \\
7.9 \\
9.7 \\
6.6\end{array}$ \\
\hline $\begin{array}{l}\text { Dried mol. sugarbeet pulp } \\
\text { Dried brewers' grains } \\
\text { Maize gluten meal }\end{array}$ & $\begin{array}{r}27.0 \\
21.8 \\
8.1\end{array}$ & $\begin{array}{l}65.6 \\
69.7 \\
46.7\end{array}$ & $\begin{array}{l}5.6 \\
2.2 \\
0.3\end{array}$ & $\begin{array}{l}24.8 \\
35.5 \\
25.1\end{array}$ \\
\hline $\begin{array}{l}\text { Sunflower meal } \\
\text { Cottonseed cake } \\
\text { Linseed cake } \\
\text { Soyabean meal sol. ext. }\end{array}$ & $\begin{array}{l}62.1 \\
39.5 \\
21.1 \\
52.0\end{array}$ & $\begin{array}{l}84.7 \\
69.2 \\
68.0 \\
78.2\end{array}$ & $\begin{array}{r}4.2 \\
1.6 \\
4.8 \\
10.8\end{array}$ & $\begin{array}{l}11.3 \\
12.4 \\
28.8 \\
26.9\end{array}$ \\
\hline $\begin{array}{l}\text { Meat meal } \\
\text { Fishmeal }\end{array}$ & $\begin{array}{l}38.9 \\
34.3\end{array}$ & $\begin{array}{l}66.8 \\
57.5\end{array}$ & $\begin{array}{l}3.8 \\
5.1\end{array}$ & $\begin{array}{l}26.0 \\
-\end{array}$ \\
\hline $\begin{array}{l}\text { Lucerne hay } \\
\text { Ensiled lucerne } \\
\text { Maize silage }\end{array}$ & $\begin{array}{l}35.9 \\
38.5 \\
57.0\end{array}$ & $\begin{array}{l}72.3 \\
59.6 \\
65.5\end{array}$ & $\begin{array}{r}-0.4 \\
-1.6 \\
-18.1\end{array}$ & $\begin{array}{r}17.5 \\
31.0 \\
8.7\end{array}$ \\
\hline $\begin{array}{l}\text { Mean value } \\
\text { s.d. }\end{array}$ & & & $\begin{array}{l}1.33 \\
6.13\end{array}$ & $\begin{array}{l}18.60 \\
10.07\end{array}$ \\
\hline
\end{tabular}

a The following equation can be derived from Orskov and McDonald (1979)

CT $(1 \mathrm{~h})=(\ln b-\ln (a+b-a s)) / c$ and solved using values in Table II.

CT $(24 h)=(\ln b-\ln (a+b-(a s+b s))) / c$ and solved using values in Table II.

anon, 1987). Michalet-Doreau et al., 1987, also recommended the use of production levels of intake and diet composition when performing in situ degradability experiments. The basal diet has been shown to have a considerable effect on degradability kinetics (Gonzales et al., 1987; Susmel et al., 1989), and rumen outflow rate (Eliman \& Orskov, 1983; Colucci et al., 1982), and hence on effective degradability (Weakley et al., 1983; Vik-Mo \& Lindberg 1985; Ganev et al., 1979; Susmel et al., 1989).
In this paper, the degradability data were interpolated with a 2-component kinetics model. This choice depended upon the methodological approach used. The progress of the degradation of the principal nutrients with time can, in fact, be distinguished from simple, theoretical firstorder kinetics (NRC, 1985; Krishnamoorthy et al., 1983; Mathers \& Miller, 1981; Robinson et al., 1986) by lag phases and different rates of bacterial attachment and enzymatic digestion. Moreover, using the nylon 
Table V. Correlation coefficients $(r)$ between in situ degradability of nitrogen and in vitro degradability $(N=16)$.

\begin{tabular}{lccc}
\hline $\begin{array}{c}\text { Degradability } \\
\text { in situ }\end{array}$ & \multicolumn{3}{c}{ Degradability in vitro } \\
\cline { 2 - 4 } & $\begin{array}{c}1 \mathrm{~h} \\
(a s)\end{array}$ & $\begin{array}{c}24 \mathrm{~h} \\
(a s+b s)\end{array}$ & $\begin{array}{c}24-1 \mathrm{~h} \\
(b s)\end{array}$ \\
\hline & & & \\
$a$ & $0.552\left(^{*}\right)$ & 0.078 & $-0.692{\left(\left(^{* *}\right)\right.}^{*}$ \\
$b$ & -0.371 & -0.035 & $0.486\left(^{*}\right)$ \\
$a+b$ & -0.014 & 0.025 & 0.048 \\
$\mathrm{DgN}$ & $0.775\left(^{* * *}\right)$ & $0.507\left(^{*}\right)$ & $-0.531\left(^{*}\right)$ \\
\hline
\end{tabular}

(*) $P<0.05 ;\left(^{* *}\right) P<0.01 ;{ }^{* * *} P<0.001$.

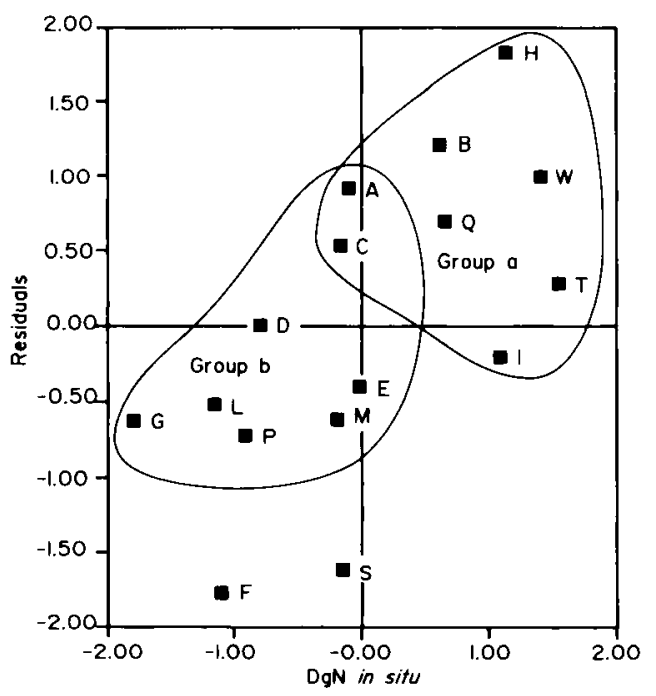

Fig. 4. Plot of the standardised residuals of regression for $\mathrm{DgN}: \mathrm{A}=$ whole soyabean meal; $\mathrm{B}=$ barley; $C=$ maize meal; $D=$ dried brewers' grains; $E=$ ensiled lucerne; $F=$ fishmeal; $G=$ maize gluten meal; $H=$ lucerne hay; $I=$ maize silage; $L=$ linseed cake; $M=$ meat meal; $P=$ dried molassed sugarbeet pulp; $Q=$ cottonseed cake; $\mathrm{S}=$ soyabean meal sol. ext.; $\mathrm{T}$ = sunflower meal; $\mathrm{W}=$ wheat. bag technique, it is difficult to obtain observations at sufficiently frequent intervals, for example less than $30 \mathrm{~min}$, or every $1 / 2 \mathrm{~h}$ for the first $6 \mathrm{~h}$. Furthermore, bacterial contamination (Varvikko, 1986; Crooker et al., 1978) can affect the degradability kinetics (Siva Bhat et al., 1988). For nearly all the feeds, the $r^{2}$ and RSD values for the $\mathrm{N} \mathrm{ki-}$ netics (Table II) confirm the good interpolation obtained by employing the Ørskov and McDonald (1979) 2-component model.

For nearly all feeds, the effective $\mathrm{N}$ degradability obtained in this current work (Table III) was lower than the "degradabilité théorique" found by INRA (Vérité et al., 1987). The most noticeable differences were for whole soya, barley, linseed cake, soyabean meal, fishmeal and the silages. Similar values to INRA (Vérité et al., 1987) were observed for wheat, dried brewers' grains and meatmeal. Higher values than those obtained by INRA were found only for maize meal and maize gluten meal. The effective degradability values for dried brewers' grains, soyabean meal, fishmeal and ensiled lucerne agree well with values obtained previously in this laboratory (Susmel et al., 1989). 
The differences between our results and those of INRA could be due to the different rumen outflow rate $(0.06$ for INRA, Vérité et al., 1987) used in the calculations, but are more likely to be due to differences in feed chemical composition and the characteristics of the basal diets.

The low correlation between $\mathrm{DgN}$ and $\mathrm{DgDM}$ values shows that it is not possible to predict the degradability of nitrogen from that of dry matter. The different behaviour of nitrogen and dry matter in the rumen, as shown in this experiment, was also observed by $\mathrm{Ha} \&$ Kennelly (1984) and Ehle et al. (1982). The subdivision of the dry matter into nitrogen and non protein organic matter fractions shows clearly that nitrogen does not necessarily have an effective degradability similar to that of NPOM, as has been already shown by Susmel et al. (1989) and Nocek (1985).

French PDIA values (Fig. 1) are generally higher than those of the Italian system (Table III), probably because of the latter's lower digestibility values, with a concomitant effect on degradability. However, the regressions between the French and Italian protein systems (Fig. 3) reveal that PDIN values are approximately equal, with a constant term of $9 \mathrm{~g}$.

The different methods for estimating energy available for bacterial synthesis (fermentable carbohydrates and degraded protein in the rumen for the Italian, and fermentable organic matter for the French system) cause a considerable effect in determining the feed PDIE contents (Fig. 2). The regression between the 2 systems shows, on average, a lower PDIE content using the Italian system, although this difference is not significant.

The protease degradability values at 1 and $24 \mathrm{~h}$, shown in Table IV, reveal, for many of the feeds, substantial differences when compared with those in situ. For the silages, this effect may have been due to the different physical form in which the samples were incubated in vitro, i.e. dried.

Examining the values in Table $\mathrm{V}$, it can be observed that the in situ degradability coefficients (i.e. $a, b$ and $a+b$ ) were generally poorly correlated with the in vitro degradability values, with $r$ (DF $=15$ ) values of less than 0.7 , even if some of the correlation coefficients were significant. A plot of the data produced widely dispersed points (not shown). A moderate but highly significant $(P<0.001)$ correlation was observed between the in situ effective degradability and the in vitro degradability value as.

The value $b$ in situ was higher than that of bs in vitro only for fishmeal and meatmeal, and this would appear to show, over the above-mentioned phenomena, that there might be a physical inhibition effect acting on the enzymatic digestion of the other feeds, possibly linked to the presence of cell-wall carbohydrates in the feeds of vegetable origin which limit the purely proteolytic attack on the part of the enzyme.

Other workers have shown a higher correlation between solubility, either in enzyme or buffer solutions, for short incubation times (from 1 to $4 \mathrm{~h}$ ) with the effective degradability measured with dacron bags (Crawford et al., 1978; Stern and Satter, 1984; Poos-Floyd et al., 1985). In particular, Poos-Floyd et al. (1985) reported a correlation coefficient of 0.82 between the quantity of residual nitrogen after $i \mathrm{~h}$ of protease incubation in vitro and the undegradable $\mathrm{N}$ fraction contained in dacron bags. Krishnamoorthy et al. (1983) reported a high rumen nitrogen degradability for mixed diets and a low in vitro solubility for the same diets, with a correspondingly low correlation coefficient. Similarly, PoosFloyd et al. (1985) showed that the correlation between in vitro and in situ degradability decreases with increasing enzyme incubation times. Krishnamoorthy et al. (1983) 
attributed this different behaviour to the fact that the degradation of protein in vitro occurs in a closed system, where there is the distinct possibility of enzyme inhibition by degradation products. The estimation of enzymatic solubility using hydrazine and chloramphenicol as inhibitors (Broderick et al., 1988) gave an average value to the effective nitrogen degradability as $83 \%$ of that in situ.

Sauvant et al. (1987) have reported a high correlation $\left(r^{2}=0.90\right)$ between the effective nitrogen degradability in situ and that obtained with the same enzymatic technique reported in this paper. Unfortunately, Sauvant et al. (1987) did not report an equation for the calculation of nitrogen degradability from the $1-$ and 24-h enzyme degradability. In the absence of a reference model, the correlation between the available in situ and in vitro data were studied using multiple regression analysis.

The regression equations contained a large constant term $(P<0.05)$, indicating that the in vitro data did not correspond to the measured in situ solubility (a) and potential degradability (b). Apart from the groups taken from the residual plot (as described above, see fig. 4), a visual appraisal of the residual plots would suggest the presence of at least 2 additional groups:

Group (a) feeds in the upper-right position of the graph (wheat, barley, maize, whole soyabean meal, sunflower meal, cottonseed cake, lucerne hay and maize silage);

Group (b) feeds in the central zone of the graph (brewers' grains, ensiled lucerne, linseed cake, maize, maize gluten meal, meat meal, whole soyabean meat and dried sugar beet pulp).

Statistical analysis produced higher $r^{2}$ values $(0.92$ and 0.79$)$ and lower RSE values (0.76 and 1.28) for Groups (a) and (b) respectively, in comparison with the "all- feeds" group. It is surprising that the composition of these additional groups was independent of the nature of the feedstuffs, so that cereals, forages and by-products could be included in the same group. Unfortunately, there were insufficient data to allow a general application of the results, so that further work with additional feeds is required to clarify this issue.

\section{ACKNOWLEDGMENT}

This research was carried out with an MPI $40 \%$ (U.O.B. Stefanon).

\section{REFERENCES}

AOAC (1975) Official Methods of Analysis. Association of Official Analytical Chemists, 12 th edn. Washington DC

ARC (1984) The nutrient Requirements of Ruminant Livestock. Suppl. 1. Agricultural Research Council, Farnham Royal, Slough, U.K.

Aufrere J. \& Cartailler D. (1988) Mise au point d'une méthode de laboratoire de prévision de la dégradabilité des protéines alimentaires des aliments concentrée dans le rumen. Ann. Zootech. 37, 255-270

Broderick G.A., Wallace R.J., Orskov E.R. \& Hansen L. (1988) Comparison of estimates of ruminal protein degradation by in vitro and in situ methods. J. Anim. Sci. 66, 1739-1745

Colucci P.E., Chase L.E. \& Van Soest P.J. (1982) Feed intake, apparent diet digestibility and rate of particulate passage in dairy cattle. $J$. Dairy Sci. 65, 1445-1456

Crawtord R.J. Jr., Hoover W.H., Sniffen C.J. \& Crooker B.A. (1978) Degradation of feedstuff nitrogen in the rumen versus nitrogen solubility in three solvents. J. Anim. Sci. 46: 1768-1775

Crooker B.A., Sniffen C.J., Hoover W.H. \& Johnson L.L. (1978) Solvents for soluble nitrogen 
measurements in feedstuffs. J. Dairy Sci. 61 , 437-447

Ehle F.R., Murphy M.R. \& Clark J.H. (1982) In situ particle size reduction on degradation of crude protein and dry matter in the rumen of dairy steers. J. Dairy Sci. 65, 963-971

Eliman M.E. \& Ørskov E.R. (1983) The effect of affecting the outflow of protein supplements from the rumen. 1. Feeding level. Anim. Prod. $38,45-51$

Ganev G., Ørskov E.R. \& Smart R. (1979) The effect of roughage or concentrate feeding and rumen retention time on total degradation of protein in the rumen. J. Agric. Sci. 93, 651-656

Gonzales J., Michalet-Doreau B. \& Poncet C. (1987) Effet du niveau d'ingestion et du pourcentage de concentré dans la ration sur la dégradabilité de l'azote in sacco chez le mouton. Reprod. Nutr. Dev. 27, 155-156

Ha J.K. \& Kennelly J.J. (1984) In situ dry matter and protein degradation of various protein sources in dairy cattle. Can. J. Anim. Sci. 64, 443-452

INRA (1988) Alimentation des bovins, ovins et caprins. (R. Jarrige, ed) INRA, Paris

ISO (1981) International standard 5725. Precision of test methods. Determination of repeatability and reproductibility by inter-laboratory test. Ref. No. 150, 5725-1981

Krishnamoorthy U., Muscato T.V., Sniffen C.J. \& Van Soest P.J. (1982) Nitrogen fractions in selected feedstuffs. J. Dairy Sci. 65, 217-225

Krishnamoorthy U., Sniffen C.J., Stern M.D. \& Van Soest P.J. (1983) Evaluation of a mathematical model of rumen digestion and an in vitro simulation of rumen proteolysis to estimate the rumen undegraded nitrogen content of feedstuffs. Br. J. Nutr. 50, 555-568

Madsen J. (1985) The basis for the proposed nordic protein system for ruminants. The AAT.PBV system. Acta Agric. Scand. 25 (Suppl.), 9-20

Madsen J. \& Hvelplund T. (1985) Protein degradation in rumen. A comparison between in vivo, nylon bag, in vitro and buffer measurements. Acta Agric. Scand. 25 (suppl.), 103-124

Mathers I.C. \& Miller E.L. (1981) Quantitative studies of feed protein degradation and the energetic efficiency of microbial protein synthesis in the rumen of sheep given chopped lucerne and rolled barley. Br. J. Nutr. 45, 587-604
Michalet-Doreau B., Vérité R., Chapoutot P. (1987) Methodologie de mesure de la dégradabilité in sacco de l'azote des aliments dans le rumen. Bull. Tech. CRZV, Theix INRA, 69, 5-7

Nocek J.E. (1985) Evaluation of specific variables affecting in situ estimates of ruminal dry matter and protein digestion. J. Anim. Sci. 60, 1347-1358

NRC (1985) Ruminant Nitrogen Usage. National Academy Press, Washington, DC, USA

Oldham J.D. (1987) Testing and implementing the modern systems: UK Feed Evaluation and Protein Requirement Systems for Ruminants. Commission of the European Communities, Luxembourg

Ørskov E.R. \& McDonald I. (1979) The estimation of protein degradability in the rumen from incubation measurements weighted according to rate of passage. J. Agric. Sci. Camb. 92, 499503

Poos-Floyd M., Klopfenstein T. \& Britton R.A. (1985) Evaluation of laboratory techniques for predicting ruminal protein degradation. J. Dairy Sci. $68,829-839$

Robinson P.H., Fadel J.G. \& Tamminga S. (1986) Evaluation of mathematical models to describe neutral detergent residue in terms of its susceptibility to degradation in the rumen. Anim. Feed Sci. Technol. 15, 249-271

Sauvant P., Aufrere J., Michalet-Doreau B., Giger S. \& Chapoutot P. (1987) Valeur nutritive des aliments concentrés simple : tables et prévision. Bull. Tech. CRVZ Theix 70, 75

Siva Bhat, Wallace R.J. \& Ørskov E.R. (1988) Study of the relation between straw quality and its colonisation by rumen micro-organisms. $J$. Agric. Sci. Camb. 110, 561-565

SPSSx (1985) SPSS.X User Guide. McGrawHill, New York

Stefanon B. \& Ovan M. (1988) Impiego di bicromato sodico per la valutazione della velocità di transito ruminale degli alimenti. Zoot. Nutr. Anim. 15, 431-438

Stern M.D. \& Satter L.D. (1984) Evaluation of nitrogen solubility and the dacron bag technique as methods for estimating protein degradation in the rumen. J. Anim. Sci. 58, 714-724

Susmel P. \& Stefanon B. (1987) Sistema per la valutazione delle protein alimentari per $\mathrm{i}$ ruminanti. Zoot. Nutr. Anim. 13, 567-582 
Susmel P., Stefanon B. \& Piasentier E. (1989) Effect of forage and concentrate intake level on rumen degradability of protein sources having different in vitro rates of $\mathrm{N}$ solubilisation. Anim. Feed Sci. Technol. 26, 231-249

Varvikko T. (1986) Microbially corrected amino acid composition of rumen-undegraded feed and amino acid degradability in the rumen of feeds enclosed in nylon bags. Br. J. Nutr. 56, $131-40$

Vérité R., Michalet-Doreau, B. Chapoutot P., Peyraud J.L. \& Poncet C. (1987) Révision du système des protéines digestibles dans l'intestin (PDI). Bull. Tech. CRVZ, Theix, INRA 70, 19-34

Vik-Mo L. \& Lindberg J.F. (1985) In sacco degradability of protein $(\mathrm{N})$ and dry matter in samples of individual feeds or combination, tested with diets medium or high in protein. Acta Agric. Scand. 35, 117-128

Weakley D.C., Stern M.D. \& Satter L.D. (1983) Factors affecting disappearance of feedstuffs from bags suspended in the rumen. J. Anim. Sci. 56, 493-507 